\title{
Adipose and Muscle Cell Co-Culture System: A Novel In Vitro Tool to Mimic the In Vivo Cellular Environment
}

\author{
Palaniselvam Kuppusamy ${ }^{1}$, Dahye Kim ${ }^{2}$, Ilavenil Soundharrajan ${ }^{1}$, Inho Hwang ${ }^{3}$ and Ki Choon Choi ${ }^{1, * \mathbb{D}}$ \\ 1 Grassland and Forage Division, National Institute of Animal Science, Rural Development Administration, \\ Cheonan 330-801, Korea; kpalaselvam@korea.kr (P.K.); ilavenil@korea.kr (I.S.) \\ 2 Faculty of Biotechnology, College of Applied Life Science, Jeju National University, Jeju 63243, Korea; \\ pioioiq10@gmail.com \\ 3 Department of Animal Science, College of Agricultural and Life Science, Jeonbuk National University, \\ Jeonju 54896, Korea; inho.hwang@jbnu.ac.kr \\ * Correspondence: choiwh@korea.kr; Tel.: +82-41-580-6752; Fax: +82-41-580-6779
}

check for updates

Citation: Kuppusamy, P.; Kim, D.; Soundharrajan, I.; Hwang, I.; Choi, K.C. Adipose and Muscle Cell Co-Culture System: A Novel In Vitro Tool to Mimic the In Vivo Cellular Environment. Biology 2021, 10, 6. https:/ /dx.doi.org/10.3390/biology 10010006

Received: 8 December 2020

Accepted: 23 December 2020

Published: 24 December 2020

Publisher's Note: MDPI stays neutral with regard to jurisdictional claims in published maps and institutional affiliations.

Copyright: (c) 2020 by the authors. Licensee MDPI, Basel, Switzerland. This article is an open access article distributed under the terms and conditions of the Creative Commons Attribution (CC BY) license (https: / / creativecommons.org/ licenses/by/4.0/).
Simple Summary: Co-culture system provides a novel platform to study interaction between different cell types in an in-vitro method. The co-cultures techniques have played key role in the understanding of cell-cell communication and relevant for drug response analysis. Co-culture system could influence therapeutic drug response in a dose dependent manner which reflects the clinical situation in patients. Also, the co-culture system may reflect a more realistic environment that similar phenotypic and functional characteristics of in vivo conditions. We also suggest that the co-culture methods as a key tool to study the interaction between adipose and muscle tissue under various environments including drug responses, production and influence of secretory factors, cell growth, and development. Therefore, the co-cultures method has been shown wide applications in cell biology study.

Abstract: A co-culture system allows researchers to investigate the complex interactions between two cell types under various environments, such as those that promote differentiation and growth as well as those that mimic healthy and diseased states, in vitro. In this paper, we review the most common co-culture systems for myocytes and adipocytes. The in vitro techniques mimic the in vivo environment and are used to investigate the causal relationships between different cell lines. Here, we briefly discuss mono-culture and co-culture cell systems and their applicability to the study of communication between two or more cell types, including adipocytes and myocytes. Also, we provide details about the different types of co-culture systems and their applicability to the study of metabolic disease, drug development, and the role of secretory factors in cell signaling cascades. Therefore, this review provides details about the co-culture systems used to study the complex interactions between adipose and muscle cells in various environments, such as those that promote cell differentiation and growth and those used for drug development.

Keywords: co-culture; in vitro technique; adipocytes; muscle; secretory factors

\section{Introduction}

In vitro co-culture techniques can be used to mimic in vivo environments and to observe interactions among cells (autocrine) and between cells (paracrine) [1]. Co-culture systems may be used to explore the mechanisms of action of drugs and their potential targets; they help to bridge the gap between mono-culture methods and animal models. Co-culture systems can be divided into two main categories, indirect methods and direct methods [2]. In the indirect methods, cells are physically separated into two different populations using trans-well inserts and/or overflow culture chambers that allow communication only via secretory factors. On the other hand, direct co-culture methods allow cell-cell interactions between different type of cells, which is typically achieved by spatially 
controlling the positions of adherent cells within a culture dish [3]. Generally, co-culture systems are used to study the secretory and transcription factors which are partially / fully involved in induction of cell differentiation, regulation of cellular proliferation, and production of metabolites for signaling cascades. A co-culture system can be used to reduce the amount of drug needed for a study, identify the target organs of a drug, and predict the adverse effects of drug metabolites [4]. Thus, this technique shows great potential for cell toxicological studies in the future and is now used chiefly for pharmacodynamic research.

Co-culture systems are widely used to study cross-talk between different cell lines, including adipocytes, endothelial cells, fibroblasts, macrophages, and muscle cells. Also, it is a crucial tool for understanding the various metabolic connections between adipose and other tissues [5]. The co-culture studies can provide realistic insights on cell-cell interactions via secretory factors that are effect in various metabolic functions such as energy homeostasis, muscle atrophy, and obesity and related co-morbidities. Previously, Ruiz-Ojeda et al. (2016) [6] investigated the co-culture relationship between adipocytes and macrophages and how they communicate under conditions that mimic obesity, insulin resistance, or inflammation. Similarly, an indirect co-culture system used to study intercellular communication between muscle and adipocyte cells was developed by Choi et al. (2013) [7]. Pre-adipocyte differentiation is regulated by differentiation myoblasts in the co-culture system, while pre-adipocytes promote adipogenic gene expression in muscle satellite cells co-cultured with pre-adipocytes. Muscle and fat tissue are major paracrine and endocrine organs that communicate with each other regarding muscle development, regulation of energy homeostasis, and insulin sensitivity [8]. For example, exercise-induced improvements in muscle function influence carbohydrate and fatty acid metabolism in the whole body as well as peripheral insulin sensitivity. Skeletal muscle communicates with other tissue types (i.e., adipose) to regulate, either directly or indirectly, whole-body energy homeostasis through myokine release [9] (Figure 1). Muscle-derived secretory proteins-including IL-6, irisin, myostatin - and some peptides, known as myokines, regulate adipogenesis via paracrine and endocrine effects [10]. Recently, Chu et al. (2016) [11] reported that porcine pre-adipocyte differentiation was inhibited in a C2C12 co-culture cells and that the expression levels of early differentiation marker genes in adipocytes were lower than those in mono-cultured adipocyte cells. Recently, Shahin-Shamsabadi [12] developed a 3D bio-fabrication method using adipocytes and myoblasts, that analyzed specifically either in direct physical contact or in close proximity such that the paracrine interaction between the cells. The physical contact between cells have been flouted in co-culture systems using transwell inserts and can be used in studies for the development of anti-obesity drugs. Anan et al. [13] studied the method for analyzing the direct interaction between adipose tissue and cardiomyocytes. The HL-1 cells suppressed the development of CD44+/CD105+ mesenchymal stem cell-like cells and lipid-laden preadipocytes from ATFs. In addition, the HL- 1 cells stimulated the secretion of adiponectin in adipose tissue fragments (ATF), whereas they decreased production of leptin in a co-culture experiment. 


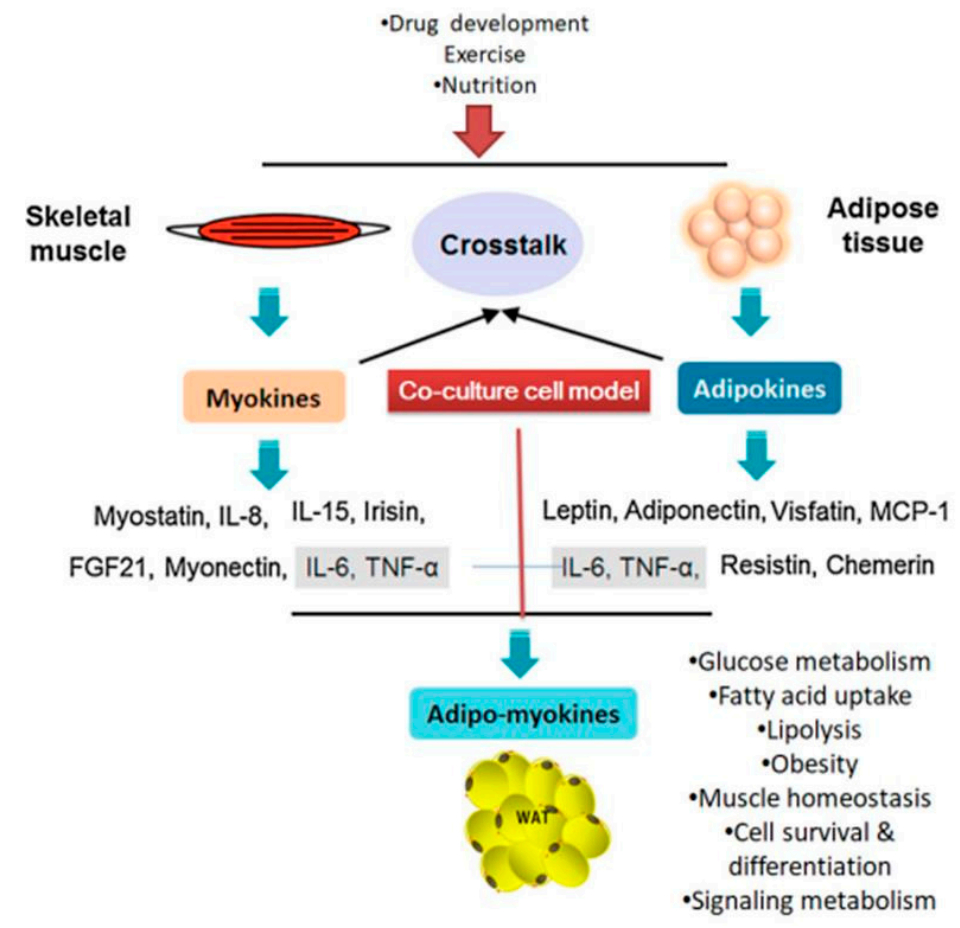

Figure 1. Cross-talk between muscle and adipose tissues is regulated by various secretory factors (adapted and modified from Li et al. (2017) [14]). WAT: white adipose tissue; TNF- $\alpha$ - tumor necrosis growth factor- alpha; FGF21: fibroblast growth factor 21; IL: interleukin.

\section{Adipocytes/Muscle Cells Co-Culture Models}

Co-culture models have been used to examine diverse cellular functions, such as interactions between muscle and nerve cells, angiogenesis, adipocyte/muscle cell crosstalk, immune cell functions, etc. [15]. Interactions between co-cultured myoblasts and adipocytes have been implicated in facilitation of muscle growth, tissue repair and muscle regeneration. These findings have led to the discovery of adipo-myokine secretory factors (AMSFs), which are produced by adipocytes and myocytes to induce differentiation and proliferation. Table 1 summarizes the findings of recent studies in co-culture systems using adipose and muscle cells.

At present, our knowledge of the interactions between adipocytes and myocytes largely stems from studies of the effects of individual adipokine factors on cultured muscle cells or adipocytes and vice versa. A wide variety of adipocyte mediated secretory molecules regulate muscle metabolism without affecting other tissues. Furthermore, in an in vitro co-culture system, myocytes were exposed to a group of free fatty acids (FFAs) and adipo-myokines $[16,17]$ that communicate signals to other organs. These studies have fueled attention towards analyses of metabolic communication between fat and muscle cells. Adipose tissue is known to protect other cell types from lipotoxicity by providing a safe place to store surplus energy. However, obesity-related dysregulation of adipose tissue promotes lipid oversupply to several non-adipocyte tissue types. This can contribute to the development of metabolic diseases, such as cardiovascular disease and liver and bone disorders. Adipose tissue is an important endocrine organ that communicates with the brain and peripheral tissues to bring about changes in whole-body energy homeostasis through a network of circulating adipokines [18]. These signaling factors include peptide hormones; chemokines such as leptin, adiponectin, resistin, visfatin, and apelin; and proinflammatory cytokines including interleukins (IL-1 $\beta$, IL-6 and IL-15) and tumor necrosis factor- $\alpha$ (TNF- $\alpha$ ). Obesity may lower the levels of circulating insulin-sensitizing adipokines such as adiponectin while increasing the levels of pro-inflammatory response molecules such as IL-6 and TNF- $\alpha$ in adipose tissues [19]. 
Table 1. Examples of co-culture model systems consisted of adipose and muscle cells.

\begin{tabular}{|c|c|c|c|}
\hline Co-Culture Model & Compounds Used & Study Findings & Ref. \\
\hline Pre-adipocytes-myoblasts & Arginine and/or trans 10, cis-12 CLA & $\begin{array}{l}\text { Increased adipogenic gene expression } \\
\text { in myoblasts }\end{array}$ & [7] \\
\hline $\begin{array}{l}\text { Bovine adipocytes and } \\
\text { pre-adipocytes }\end{array}$ & Adipogenic induction medium & $\begin{array}{l}\text { Increase lipolytic response and } \\
\text { glycerol release }\end{array}$ & [20] \\
\hline 3T3-L1 adipocyte-C2C12 cells & Ferulic acid & $\begin{array}{c}\text { Increase lipolytic profile and glycerol } \\
\text { release }\end{array}$ & [21] \\
\hline C2C12 myoblasts-3T3-L1 adipocytes & Adipocytes medium induced IL-6 & $\begin{array}{l}\text { Suppress the differentiation of } \mathrm{C} 2 \mathrm{C} 12 \\
\text { cells }\end{array}$ & [22] \\
\hline $\begin{array}{l}\text { Differentiated C2C12 with 3T3-L1 } \\
\text { cells }\end{array}$ & Calcitriol & $\begin{array}{c}\text { Decreased anti-inflammatory } \\
\text { cytokines production }\end{array}$ & [23] \\
\hline 3T3-L1 (adipocyte)-L6 muscle cell line & $\begin{array}{l}\text { Differentiation media without } \\
\text { additives }\end{array}$ & $\begin{array}{l}\text { Co-culture adipocyte cells increased } \\
\text { GPDH activity }\end{array}$ & [24] \\
\hline Human fat and skeletal muscle cells & $\begin{array}{l}\text { Differentiation medium with } 1 \\
\mathrm{pmol} / \mathrm{L} \text { insulin }\end{array}$ & $\begin{array}{l}\text { adipocyte induce a paracrine } \\
\text { perturbation in muscle cells }\end{array}$ & [25] \\
\hline $\begin{array}{l}\text { 3T3-L1 preadipocytes-differentiated } \\
\text { C2C12 }\end{array}$ & DMEM differentiation medium & $\begin{array}{l}\mathrm{C} 2 \mathrm{C} 12 \text { suppressed the mRNA, } \\
\text { protein expression of glucocorticoids } \\
\text { receptor }\end{array}$ & [11] \\
\hline $\begin{array}{l}\text { C2C12 myocytes and 3T3-L1 } \\
\text { adipocytes }\end{array}$ & $\begin{array}{l}\text { Adipocyte conditioned medium with } \\
\text { Leucine }\end{array}$ & $\begin{array}{l}\text { Modulation of muscle and adipocyte } \\
\text { energy metabolism }\end{array}$ & [26] \\
\hline $\begin{array}{l}\text { C2C12 myocytes and 3T3-L1 } \\
\text { pre-adipocytes }\end{array}$ & Zinc oxide nanoparticles & $\begin{array}{l}\text { Increased expression of antioxidant } \\
\text { enzymes and mRNA expression }\end{array}$ & [27] \\
\hline $\begin{array}{l}\text { 3T3-L1 adipocytes with RAW } 264 \\
\text { macrophage }\end{array}$ & Dietary calcium & $\begin{array}{l}\text { Reduce the inflammatory cytokine } \\
\text { and oxidative stress in adipocytes }\end{array}$ & [28] \\
\hline $\begin{array}{l}\text { 3T3-L1 adipocytes with splenocytes } \\
\text { cells }\end{array}$ & Lipopolysaccharides (LPS) & $\begin{array}{c}\text { Elevated cytokine secretion (TNF-a, } \\
\text { IL-6, MCP-1) }\end{array}$ & [29] \\
\hline Murine adipocytes-C2C12 cells & Leucine and calcitriol & $\begin{array}{l}\text { Decrease energy storage in } \\
\text { adipocytes and increasing fatty acid } \\
\text { utilization in } \mathrm{C} 2 \mathrm{C} 12\end{array}$ & [30] \\
\hline $\begin{array}{l}\text { 3T3-L1 pre-adipocytes and C2C12 } \\
\text { muscle cells }\end{array}$ & DMEM/FBS growth medium & $\begin{array}{l}\text { Promote the mitochondrial biogenesis } \\
\text { bydirect activation of SIRT1 in both } \\
\text { cells }\end{array}$ & [31] \\
\hline $\begin{array}{l}\text { 3T3-L1 pre-adipocytes and L6 muscle } \\
\text { cells }\end{array}$ & DMEM/F12 supplemented with BSA & $\begin{array}{l}\text { Oxygen species production and level } \\
\text { of Glut1 mRNA and protein } \\
\text { increased in L6 cells }\end{array}$ & [32] \\
\hline $\begin{array}{l}\text { Primary human adipocyte and } \\
\text { skeletal myotubes }\end{array}$ & Low serum differentiation medium & $\begin{array}{l}\text { Understating the metabolic function } \\
\text { of intra muscular adipogenesis } \\
\text { (lipolytic activity) }\end{array}$ & [17] \\
\hline 3T3-L1 cells with J-6 cells & Defined Medium for co-cultured cells & $\begin{array}{l}\text { Low level of IGF-1 IGF-II are not } \\
\text { likely to play a role in intercellular } \\
\text { communication between these cells }\end{array}$ & [1] \\
\hline $\begin{array}{l}\text { Porcine pre-adipocytes and muscle } \\
\text { satellite cells }\end{array}$ & DMEM/F12 medium & $\begin{array}{l}\text { Induce cell growth and proliferation } \\
\text { meanwhile, inhibited the cell } \\
\text { differentiation }\end{array}$ & [33] \\
\hline $\begin{array}{l}\text { Skeletal muscle (L6)-adipocyte } \\
\text { (3T3-L1) }\end{array}$ & $\begin{array}{l}\text { Specific differentiation medium for } \\
\text { both cells }\end{array}$ & $\begin{array}{l}\text { IL- } 6 \text { cytokine plays main role in } \\
\text { cross-talk between these cells }\end{array}$ & [34] \\
\hline 3T3-L1 and L6 cell line & $\begin{array}{l}\text { Differentiation medium containing } \\
\qquad 5 \% \mathrm{HS}\end{array}$ & $\begin{array}{l}\text { Adipocyte differentiation inhibited } \\
\text { and suppress the lipogenic gene } \\
\text { expression }\end{array}$ & [35] \\
\hline
\end{tabular}




\section{Monoculture vs. Co-Culture}

\subsection{Monoculture Techniques}

Cell culture techniques permit us to understand development-related diseases, drug activity, secretory protein profiles, and different types of cell-cell interactions. These techniques are mainly used to evaluate the preliminary level of drug toxicity in in vitro disease models, and can be used to identify gene function in the laboratory environment [36]. Though cell culture models are very common, they are limited in their ability to represent complex in vivo environments, and the results may not be relevant in certain cases [37]. Co-culture models more accurately represent the natural environment. Also, single cell culture methods are most commonly used to grow a single type of cell, but recently $2 \mathrm{D}$ and $3 \mathrm{D}$ culture methods have gained popularity due to their diverse biomedical and clinical applications [38].

\subsection{Co-Culture Techniques}

Co-cultures models are highly applicable to drug development research as they offer a more in vivo-like tissue model without the complications associated with animal models. The cellular growth and differentiation mechanisms in a co-culture system may differ from those in a mono-culture system [39]. Thus, it is essential to study the mechanisms of cellular cross-talk between different cell types in co-culture systems [40]. Furthermore, some cells are not easy to grow in in vitro mono-culture systems and will not exhibit preferred in vivo physiological behaviors [41], but may be successfully co-cultured or exhibit the behavior of choice in a co-culture system.

Studies of co-culture-related phenomena are generally kept as simple as possible. For instance, co-cultured muscle satellite cells were analyzed by determining variations in cell number, morphological alterations, and the number of cells that differentiated into multinucleated myotubes [1]. Similarly, pre-adipocyte status in co-culture systems has been assessed mainly by determining cell growth and morphological changes. Recently, the importance of complex interactions between muscle and adipose cells has been understood in regard to the pathogenesis of non-communicable metabolic diseases. Adipocytes are present at different sites (abdomen, hip, thigh, etc.) that are inhomogeneous and differ quite considerably in their metabolic and inflammatory functions, and can be clearly differentiated in part by adipose depot differences. Hence, use of co-culture systems could advance our understanding of the types of interactions between muscle and fat tissues and other organs. Also, this system provides a more physiologically accurate picture with which to examine the role of secreted factors in governing cell-cell interactions [42].

Dietze et al. (2002) [25] reported that co-culture of human myocytes and adipocytes enhanced adipose-derived secretory factor signaling in cross-talk with skeletal muscle cells, mainly insulin-stimulated phosphorylation of protein kinase B (Akt) and insulin receptor substrate 1 (IRS-1) in myocytes. There is sound evidence at the phenotypic and cellular levels that adipose-mediated secretory factors interfere with muscle insulin signaling and homeostasis [43]. Endocrine cross-talk between whole fat tissue and whole skeletal muscle have yet to be examined ex vivo. Furthermore, Tishinsky et al. (2014) [44] studied the effects on dietary fatty acid consumption on regulation of adipose tissue-skeletal muscle cross-talk in a co-culture system. The study found that dietary fatty acid intake regulates excess adipose fat depots. Similarly, Bruckbauer and Zemel (2011) [31] reported on calcitriol and leucine modulation of sirtuin 1 (SIRT1) in adipose tissue and skeletal muscle, and found that SIRT1 is the central signaling target that mediates the effects of calcitriol and leucine. In sum, adiposity is highly related with changes in glucose and fatty acid metabolism.

\section{Co-Culture System Advantages and Disadvantages}

Co-culture systems are used to culture and differentiate cells in vitro and are of great importance to the process of the drug development as well as treatment of incurable pathologies [45]. In vitro monoculture models are commonly used to study complex mechanistic aspects of drug response and the paracrine effects of drugs. However, co-culture 
techniques may provide a simplified, more cost-effective, high-throughput technique that utilizes fewer animals and allows for more focused analysis.

However, as this is a somewhat simplistic approach, these in vitro cell culture systems may produce inaccurate results; they may, for example, examine an inadequate number of variables and not include different types of cells and their responses that would be necessary to authentically duplicate in vivo aspects of the foreign body response (FBR). As a result, in vitro models may not be able to predict certain in vivo phenotypes. For instance, a major contradiction between in vitro and in vivo models is the observed lack of inflammatory stimulation in vitro [46].

2D cell culture has many advantages, e.g., it is relatively simple and easy to handle cells in vitro and to perform different functional tests. Cellular interactions are responsible for cell proliferation, differentiation, expression of genes and proteins, responsiveness to stimuli, drug responses and other cellular metabolic functions [47,48]. Also, changes in the structure of cells can affect their function and metabolism [49]. Moreover, cells in a monolayer have unlimited access to the components of the medium — such as $\mathrm{O}_{2}$, nutrients, metabolites, and signaling molecules-which is not generally the case in 3D systems.

One problem of co-culture systems concerns the many variables, including the composition of the medium, volume, and duration of culture period and the degree of similarity and separation between two different cell populations, which need to be optimized [50].

The animal models are used to study the molecular mechanisms of development and progression of diabetes and cancer and metabolic diseases. However, the transgenic animal's experiments are expensive, difficult to visualize, and they are not completely demonstrative of human physiology or genetics. In addition, it needs to get associated ethical clearance [51].

\section{Secreted Factors in Co-Culture Model}

Growth factors are biochemical signals that are naturally produced by cells/tissues and are responsible for cell growth, development and repair. They include fibroblast growth factors (FGFs), insulin-like growth factor-1 (IGF-1), $\beta$-nerve growth factor ( $\beta$-NGF), transforming growth factor- $\beta$ (TGF $\beta$ ), etc. For example, the L6 cells were co-cultured with 3T3-L1 cells for $24 \mathrm{~h}$, followed by their stimulation with insulin $(100 \mathrm{ng} / \mathrm{mL})$ showed increases Akt phosphorylation at both sites (ser473 and ser308) in adipocytes. However, these effects were partially inhibited by 3T3-L1 co-culture cells [32]. Therefore, the coculture system can be potent way to study cell signaling between two different cells like in vivo model.

Cytokines are a diverse group of secretory substances that play specific roles in the interactions and/or communications between two or more different type of cells. They include interleukins (ILs), tumor necrosis factor, etc. Also, the chemokines include chemerin, resistin, apelin, visfatin, leptin, etc. [52].

The secretory factors play key functions in the metabolism, pathophysiology conditions including cardiovascular complications, diabetes, obesity and some cancers. Secreted factors may include many cytokines and/or chemokines such as TNF- $\alpha$, IL-6, -8 , as well as leptin, myostatin, and adiponectin. These secreted factors are secreted by not only adipose tissues but also present in the other tissues/cells including macrophages and muscle cells etc. [53]. In particular, the WAT are major endocrine organ and it is increasingly cross linked with muscle tissue in term of energy homeostasis and maintain the blood glucose level in the body. The adipocytes and myocytes cells secrete a broad range of bioactive proteins. In general, the adipocytes secretory proteins are termed as adipokines and myokines for muscle cells. Myokines and adipokine are important secretory molecules to be involved in local autocrine/paracrine interactions within muscle and adipose tissue respectively. There are some similar secretory proteins were identified between the myokines and adipokines, in that both groups can produce some commonality inflammation related secretory proteins, for example IL-6, Il-8 and MCP-1 (Monocyte Chemoattractant Protein-1). Trayhurn et al. [54] studied the IL-6 secreted from muscle could enhance the 
lipolysis in adipose tissue, whereas adipocyte derived IL-6 may induce insulin resistance in muscle cells.

In addition, the adipogenic factors include glucocorticoids, PPAR- $\gamma$ agonists, insulin, and basic human fibroblast growth factor (hFGF-B) are often found that to induce cellular network assembly and/or the communication of muscle and macrophage cells [55]. Recently, Cui et al. [56] reported the communication between muscle cell and adipocytes of chicken using a trans-well co-culture chamber. After co-culture, the MSCs in the proliferation stage (20\% confluence) was inhibited the differentiation of intramuscular preadipocytes (IMPs). On the other hand, the Muscle satellite cells (MSCs) in the stationary phase growth $(100 \%$ confluence) would certainly accelerate the differentiation of IMPs. In addition, the gene expression levels of PPAR $\gamma$, LPL and ACC accelerated in the treated co-culture cells.

\section{Models for Co-Culture System}

Muscle-adipocyte interactions involve a complex set of signaling events that act at multiple levels in the developmental process [57]. Skeletal muscle and fat both originate from mesenchymal stem cell precursors. That adipocytes and muscle cells have similar origins might suggest a strong degree of communication between these two cell types (Figure 2). On the other hand, muscle influences energy metabolism and inflammatory conditions in the whole body through active metabolism of fuel. During these phenomena, muscle metabolites and secretory molecules communicate with adipose and other tissues in a complex manner. Physical activity may reduce fat deposition through secretion of beneficial myokines from muscle tissue and increase insulin sensitivity and muscle mass [58]. Adipose tissue may be affected by muscle inflammation. De Boer et al. (2014) [59] studied the cross-talk between adipocytes and macrophages in an obese adipose tissue model. The proinflammatory adipokine profile develops through adipocyte-macrophage cross-talk and leads to decreased insulin sensitivity within adipocytes as well as in other metabolic organs, such as skeletal muscle and liver. In addition, dysfunctional adipose tissue secretes distress signaling molecules, such as chemokines and free fatty acids, which induce the pro-inflammatory cytokine production that characterizes obese adipose tissue.

Recently, co-culture techniques have been used to examine the importance of (in)direct contact between two cell types, such as muscle cells and adipocytes [60,61]. Seo et al. (2019) [22] found that muscle cell growth is disturbed by adipocytes and dominate the culture muscle cells when they are co-cultured either muscle or adipocyte cell culture. Adipocytes may communicate with myocytes to inhibit muscle cell differentiation through paracrine signaling. Mouse 3T3-L1 adipocytes attenuate the differentiation of $\mathrm{C} 2 \mathrm{C} 12$ skeletal muscle cells by downregulating myogenin gene expression and upregulating that of myostatin, atrogin-1, and MuRF-1. Also, 3T3-L1 adipocytes induce secretion of IL-6 in C2C12 muscle cells. This area of research requires further investigation, including research into the beneficial effects of individual myokines and the mechanisms underlying muscle-adipose tissue interactions that could be employed to develop new drugs to treat chronic metabolic diseases. Also, it is important to carry out clinical studies in order to translate animal data into novel therapeutic approaches to human system $[46,62]$. 

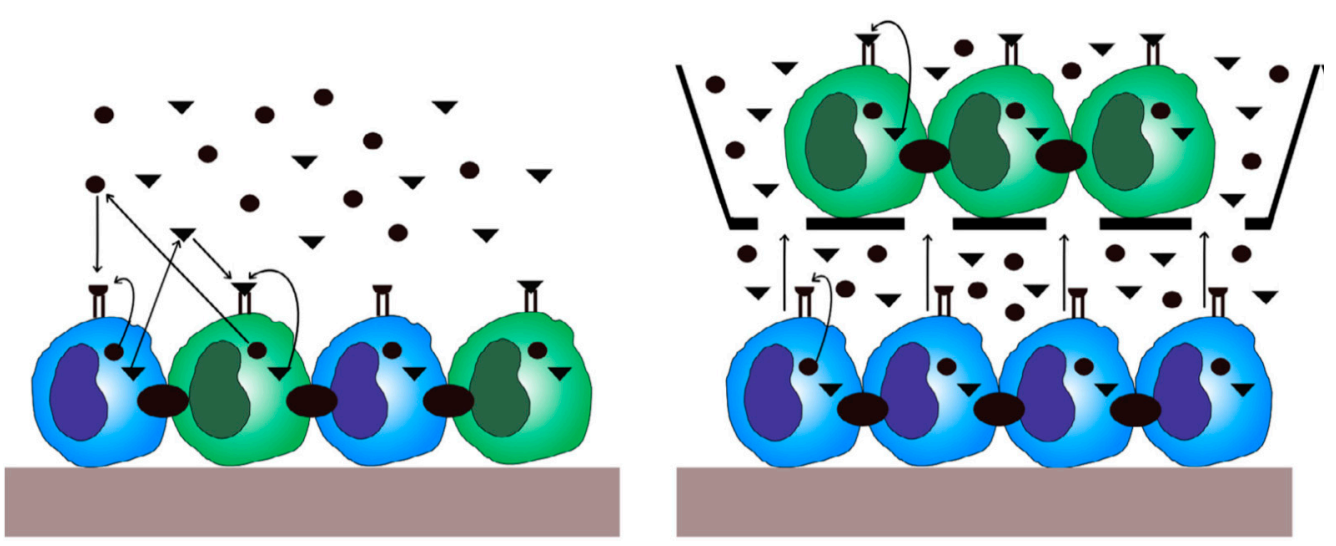

Figure 2. Diagrammatic representation of the cell interactions in the co-culture systems. In the direct coculture model (a) cell-cell communication occurs through direct cell contact, while (b) indirect cell contact is communicated by autocrine and paracrine approaches (adapted from Borciani et al. (2020) [63]).

\subsection{Direct Co-Culture Models}

Direct co-culture systems may vary in the conditions of intercellular interactions, which include cell-cell and/or cell-matrix interactions, release of secretory factors, and a combination of the above [64]. Direct physical contact promotes cell-cell interactions through surface proteins that mimics the actual in vivo situation and may increase transduction of cellular signals between various types of cells [65]. A direct co-culture model may produce different results depending on the number of cells that are seeded and the nature of the scaffolds that are used. Thus, some authors attempted to determine whether secreted factors alone, or a combination of secreted factors and other modes of cell-cell communication, play a predominant role, by controlling a single variable [66]. However, physical contact between cells may play a role in chondro-induction as compared with soluble factors alone, and paracrine factors were not shown to be involved in the expression of chondrogenic genes [67].

\subsection{Indirect Co-Culture Models}

Co-culture systems with culture inserts can be used to study cell-cell interactions under normal, differentiation, and special development environments [68]. Indirect contact coculture models physically separate the different cell types using a trans-well chamber, membrane inserts, and/or a micro-patterned co-culture set up [69]. Two- and three-dimensional co-culture systems have been used to examine the secretome of obese adipocytes and to show that it negatively affects the contractile complex of myocytes; this represents an important advancement in our understanding of adipocyte-myocyte interactions in metabolic disease states [70]. Notably, co-culture systems are used to study the mechanisms of two-way communication between two different cell populations, in which different paracrine factors are secreted by both cell types and equally affect the two cell types. Secretory effects can be investigated using trans-well porous membrane inserts that separate different populations of cells in co-culture plates/discs (Figure 2). Importantly, indirect co-culture has been used to determine the importance of trophic factor secretion in cellular differentiation-related processes [71].

Cells grown in an insert can be co-cultured in a culture dish containing a different cell type to assess cellular communication through paracrine signaling in the absence of physical contact between cells. The insert co-culture system provides various benefits over other co-culture models, i.e., bidirectional signaling, population-specific detection of cellular changes, conservation of cell polarity, and so on [72]. Moreover, co-culture techniques can be utilized in cancer, angiogenesis, inflammation and cell differentiation studies. These coculture systems are most important for the study of the complex cellular communications 
that exist between different cell types-including nerve, muscle, adipose, and immune cells-particularly in the contexts of inflammation, regulation of fat deposition and muscle development. In addition, depending on the co-culture set-up, the cell populations can be perfectly mixed or partially separated using membrane inserts containing $0.45 \mu \mathrm{M}$ pores. Generally, co-culture with inserts is used to divide the cell populations using permeable membranes to control population interactions, which can be the main factor in achieving a stable cell culture system [73]. Separation of two different cell populations needs to be done carefully to ensure that the environment is relevant to the primary aim of the co-culture experiments. For example, if two cellular populations are dependent on each other for exchange of substances, the permeability of the materials must be considered, given that diffusion rates within specific ranges may be required. When diffusion rates are too low, important nutrients cannot be exchanged between cells. Also, a diffusion rate that is too high may spoil the whole system [74]. Therefore, it is necessary to take these factors into consideration when expanding co-culture systems to greater volumes, as diffusion is a distance-dependent phenomenon [40].

Recently, Saldana et al. (2017) [75] studied co-cultures of MSC and immune cells using a cell culture insert consisting of a polyester membrane with a $0.4 \mu \mathrm{m}$ pore size that allows endocrine contact between the two cell types in the absence of direct cell-cell contact. Similarly, Nitta et al. (2013) [29] reported on a co-culture of activated splenocytes and adipocytes without direct cell-cell contact and showed that the co-cultured cells increased secretion of TNF- $\alpha$ in a time-dependent manner that reached a maximum at $20 \mathrm{~h}$. Cocultured splenocytes and adipocytes can communicate via cell surface molecules, which can in turn activate intracellular signaling pathways via TNF- $\alpha$ receptor signaling cascades.

\section{Conclusions}

Recently, co-culture systems of myogenic and adipogenic cells have been used to explore several important phenomena, including whether secretory factors released by the cells alter the viability and development of pre-adipocytes into mature adipocytes. Paracrine factors may influence the activity of these co-cultured cells, and significant differences exist between individual strains of muscle satellite cells and pre-adipocytes. Continued modification and use of this co-culture model provides a fuller description of the in vivo environment than is possible with the use of single in vitro cultures. This system will prove valuable in elucidating the intracellular communication that is necessary for growth and development of muscle and adipose tissue under different conditions.

Author Contributions: Conceptualization, methodology, data curation, writing - original draft, K.C.C. and P.K.; Resources, Project administration, K.C.C., I.H. and I.S.; Methodology, P.K. and D.K.; Data curation, methodology, P.K.; Writing-review and editing, P.K., K.C.C., I.H. and I.S. All authors have read and agreed to the published version of the manuscript.

Funding: This research work was supported by Cooperative Research Program for Agriculture Science \& Technology Development Project (project no. PJ01090302) entitled “Technical development to increase utilization of Italian ryegrass in livestock" funded by RDA, Korea. This study was also supported by Postdoctoral Fellowship Program of National Institute of Animal Science funded by RDA, Korea.

Data Availability Statement: Not Applicable.

Conflicts of Interest: The authors declare no conflict of interest.

\section{References}

1. Dodson, M.V.; Vierck, J.L.; Hossner, K.L.; Byrne, K.; McNamara, J.P. The development and utility of a defined muscle and fat co-culture system. Tissue Cell 1997, 29, 517-524. [CrossRef]

2. Levorson, E.J.; Santoro, M.; Kasper, F.K.; Mikos, A.G. Direct and indirect co-culture of chondrocytes and mesenchymal stem cells for the generation of polymer/extracellular matrix hybrid constructs. Acta Biomater. 2014, 10, 1824-1835. [CrossRef] [PubMed]

3. Venter, C.; Niesler, C. A triple co-culture method to investigate the effect of macrophages and fibroblasts on myoblast proliferation and migration. Biotechniques 2018, 64, 52-58. [CrossRef] [PubMed]

4. Stanford, K.I.; Goodyear, L.J. Muscle-Adipose Tissue Cross-Talk. Cold Spring Harb. Perspect. Med. 2018, 8. [CrossRef] 
5. Gupta, R.K. Adipocytes. Curr. Biol. 2014, 24, R988-R993. [CrossRef]

6. Ruiz-Ojeda, F.J.; Rupérez, A.I.; Gomez-Llorente, C.; Gil, A.; Aguilera, C.M. Cell Models and Their Application for Studying Adipogenic Differentiation in Relation to Obesity: A Review. Int. J. Mol. Sci. 2016, 17, 1040. [CrossRef]

7. Choi, S.H.; Chung, K.Y.; Johnson, B.J.; Go, G.W.; Kim, K.H.; Choi, C.W.; Smith, S.B. Co-culture of bovine muscle satellite cells with preadipocytes increases PPAR $\gamma$ and C/EBP $\beta$ gene expression in differentiated myoblasts and increases GPR43 gene expression in adipocytes. J. Nutr. Biochem. 2013, 24, 539-543. [CrossRef]

8. Chen, W.; Wang, L.; You, W.; Shan, T. Myokines mediate the cross-talk between skeletal muscle and other organs. J. Cell. Physiol. 2020. [CrossRef]

9. Oh, K.-J.; Lee, D.S.; Kim, W.K.; Han, B.S.; Lee, S.C.; Bae, K.-H. Metabolic Adaptation in Obesity and Type II Diabetes: Myokines, Adipokines and Hepatokines. Int. J. Mol. Sci. 2016, 18, 8. [CrossRef]

10. Giudice, J.; Taylor, J.M. Muscle as a paracrine and endocrine organ. Curr. Opin. Pharm. 2017, 34, 49-55. [CrossRef]

11. Chu, W.; Wei, W.; Yu, S.; Han, H.; Shi, X.; Sun, W.; Gao, Y.; Zhang, L.; Chen, J. C2C12 myotubes inhibit the proliferation and differentiation of 3T3-L1 preadipocytes by reducing the expression of glucocorticoid receptor gene. Biochem. Biophys. Res. Commun. 2016, 472, 68-74. [CrossRef] [PubMed]

12. Shahin-Shamsabadi, A.; Selvaganapathy, P.R. A 3D self-assembled in vitro model to simulate direct and indirect interactions between adipocytes and skeletal muscle cells. Adv. Biosyst. 2020, 4, 2000034. [CrossRef] [PubMed]

13. Anan, M.; Uchihashi, K.; Aoki, S.; Matsunobu, A.; Ootani, A.; Node, K.; Toda, S. A promising culture model for analyzing the interaction between adipose tissue and cardiomyocytes. Endocrinology 2011, 152, 1599-1605. [CrossRef]

14. Li, F.; Li, Y.; Duan, Y.; Hu, C.-A.A.; Tang, Y.; Yin, Y. Myokines and adipokines: Involvement in the crosstalk between skeletal muscle and adipose tissue. Cytokine Growth Factor Rev. 2017, 33, 73-82. [CrossRef] [PubMed]

15. Fernandez, L.A.; MacSween, J.M.; Robson, D.A. Growth of B cell colonies independent of T cell contact. Immunol. Lett. 1989, 22, 167-171. [CrossRef]

16. Dyck, D.J.; Heigenhauser, G.J.; Bruce, C.R. The role of adipokines as regulators of skeletal muscle fatty acid metabolism and insulin sensitivity. Acta Physiol. 2006, 186, 5-16. [CrossRef]

17. Kovalik, J.-P.; Slentz, D.; Stevens, R.D.; Kraus, W.E.; Houmard, J.A.; Nicoll, J.B.; Lea-Currie, Y.R.; Everingham, K.; Kien, C.L.; Buehrer, B.M.; et al. Metabolic remodeling of human skeletal myocytes by cocultured adipocytes depends on the lipolytic state of the system. Diabetes 2011, 60, 1882-1893. [CrossRef]

18. Coelho, M.; Oliveira, T.; Fernandes, R. Biochemistry of adipose tissue: An endocrine organ. Arch. Med. Sci. AMS 2013, 9, 191-200. [CrossRef]

19. Trayhurn, P.; Wood, I.S. Signalling role of adipose tissue: Adipokines and inflammation in obesity. Biochem. Soc. Trans. 2005, 33, 1078-1081. [CrossRef]

20. Strieder-Barboza, C.; Thompson, E.; Thelen, K.; Contreras, G.A. Technical note: Bovine adipocyte and preadipocyte co-culture as an efficient adipogenic model. J. Dairy Sci. 2019, 102, 3622-3629. [CrossRef]

21. Kuppusamy, P.; Soundharrajan, I.; Hwang, I.; Kim, D.; Choi, K.C.; National Institute of Animal Science, Rural Development Ad-ministration, Cheonan, Korea. Unpublished work. 2020.

22. Seo, K.; Suzuki, T.; Kobayashi, K.; Nishimura, T. Adipocytes suppress differentiation of muscle cells in a co-culture system. Anim. Sci. J. 2019, 90, 423-434. [CrossRef] [PubMed]

23. Choi, H.; Myung, K. Calcitriol enhances fat synthesis factors and calpain activity in co-cultured cells. Cell Biol. Int. 2014, 38, 910-917. [CrossRef] [PubMed]

24. Choi, C.-W.; Cho, W.-M.; Yeon, S.-H.; HwangBo, S.; Song, M.-K.; Park, S.; Baek, K.-H. Comparison between Single and Co-culture of Adipocyte and Muscle Cell Lines in Cell Morphology and Cytosolic Substances. J. Anim. Sci. Technol. 2012, 54, 103-109. [CrossRef]

25. Dietze, D.; Koenen, M.; Röhrig, K.; Horikoshi, H.; Hauner, H.; Eckel, J. Impairment of insulin signaling in human skeletal muscle cells by co-culture with human adipocytes. Diabetes 2002, 51, 2369-2376. [CrossRef] [PubMed]

26. Sun, X.; Zemel, M.B. Leucine modulation of mitochondrial mass and oxygen consumption in skeletal muscle cells and adipocytes. Nutr. Metab. 2009, 6, 26. [CrossRef] [PubMed]

27. Pandurangan, M.; Veerappan, M.; Kim, D.H. Cytotoxicity of zinc oxide nanoparticles on antioxidant enzyme activities and mRNA expression in the cocultured C2C12 and 3T3-L1 cells. Appl. Biochem. Biotechnol. 2015, 175, 1270-1280. [CrossRef]

28. Sun, X.; Zemel, M.B. Calcitriol and calcium regulate cytokine production and adipocyte-macrophage cross-talk. J. Nutr. Biochem. 2008, 19, 392-399. [CrossRef]

29. Nitta, C.F.; Orlando, R.A. Crosstalk between immune cells and adipocytes requires both paracrine factors and cell contact to modify cytokine secretion. PLoS ONE 2013, 8, e77306. [CrossRef]

30. Sun, X.; Zemel, M.B. Leucine and calcium regulate fat metabolism and energy partitioning in murine adipocytes and muscle cells. Lipids 2007, 42, 297-305. [CrossRef]

31. Bruckbauer, A.; Zemel, M.B. Effects of dairy consumption on SIRT1 and mitochondrial biogenesis in adipocytes and muscle cells. Nutr. Metab. 2011, 8, 91. [CrossRef]

32. Kudoh, A.; Satoh, H.; Hirai, H.; Watanabe, T.; Shimabukuro, M. Preliminary Evidence for Adipocytokine Signals in Skeletal Muscle Glucose Uptake. Front Endocrinol. 2018, 9, 295. [CrossRef] [PubMed] 
33. Yan, J.; Gan, L.; Yang, H.; Sun, C. The proliferation and differentiation characteristics of co-cultured porcine preadipocytes and muscle satellite cells in vitro. Mol. Biol. Rep. 2013, 40,3197-3202. [CrossRef] [PubMed]

34. Seyoum, B.; Fite, A.; Abou-Samra, A.B. Effects of 3T3 adipocytes on interleukin-6 expression and insulin signaling in L6 skeletal muscle cells. Biochem. Biophys. Res. Commun. 2011, 410, 13-18. [CrossRef] [PubMed]

35. Park, S.; Baek, K.; Choi, C. Suppression of adipogenic differentiation by muscle cell-induced decrease in genes related to lipogenesis in muscle and fat co-culture system. Cell Biol. Int. 2013, 37, 1003-1009. [CrossRef] [PubMed]

36. Jensen, C.; Teng, Y. Is It Time to Start Transitioning From 2D to 3D Cell Culture? Front. Mol. Biosci. 2020, 7, 33. [CrossRef]

37. Hausman, G.J.; Poulos, S.P. A method to establish co-cultures of myotubes and preadipocytes from collagenase digested neonatal pig semitendinosus muscles. J. Anim. Sci. 2005, 83, 1010-1016. [CrossRef]

38. Duval, K.; Grover, H.; Han, L.-H.; Mou, Y.; Pegoraro, A.F.; Fredberg, J.; Chen, Z. Modeling Physiological Events in 2D vs. 3D Cell Culture. Physiology 2017, 32, 266-277. [CrossRef]

39. Xie, X.; Zhu, J.; Hu, X.; Dai, L.; Fu, X.; Zhang, J.; Duan, X.; Ao, Y. A co-culture system of rat synovial stem cells and meniscus cells promotes cell proliferation and differentiation as compared to mono-culture. Sci. Rep. 2018, 8, 7693. [CrossRef]

40. Goers, L.; Freemont, P.; Polizzi, K.M. Co-culture systems and technologies: Taking synthetic biology to the next level. J. R. Soc. Interface 2014, 11. [CrossRef]

41. Wu, M.H.; Huang, S.B.; Lee, G.B. Microfluidic cell culture systems for drug research. Lab Chip 2010, 10, 939-956. [CrossRef]

42. Kelley, D.E.; Goodpaster, B.H. Stewing in Not-So-Good Juices: Interactions of Skeletal Muscle with Adipose Secretions. Diabetes 2015, 64, 3055-3057. [CrossRef] [PubMed]

43. Wohlers, L.M.; Sweeney, S.M.; Ward, C.W.; Lovering, R.M.; Spangenburg, E.E. Changes in contraction-induced phosphorylation of AMP-activated protein kinase and mitogen-activated protein kinases in skeletal muscle after ovariectomy. J. Cell. Biochem. 2009, 107, 171-178. [CrossRef] [PubMed]

44. Tishinsky, J.M.; De Boer, A.A.; Dyck, D.J.; Robinson, L.E. Modulation of visceral fat adipokine secretion by dietary fatty acids and ensuing changes in skeletal muscle inflammation. Appl. Physiol. Nutr. Metab. 2014, 39, 28-37. [CrossRef] [PubMed]

45. Romanazzo, S.; Forte, G.; Morishima, K.; Taniguchi, A. IL-12 involvement in myogenic differentiation of C2C12 in vitro. Biomater. Sci. 2015, 3, 469-479. [CrossRef] [PubMed]

46. Holt, D.J.; Chamberlain, L.M.; Grainger, D.W. Cell-cell signaling in co-cultures of macrophages and fibroblasts. Biomaterials 2010, 31, 9382-9394. [CrossRef] [PubMed]

47. Pampaloni, F.; Reynaud, E.G.; Stelzer, E.H. The third dimension bridges the gap between cell culture and live tissue. Nat. Rev. Mol. Cell Biol. 2007, 8, 839-845. [CrossRef]

48. Breslin, S.; O'Driscoll, L. Three-dimensional cell culture: The missing link in drug discovery. Drug Discov. Today 2013, 18, $240-249$. [CrossRef]

49. Nelson, J. Structure and Function in Cell Signall; Wiley Publisher: Hoboken, NJ, USA, 2008; Chapter 1-3, pp. 1-95.

50. Kapałczyńska, M.; Kolenda, T.; Przybyła, W.; Zajączkowska, M.; Teresiak, A.; Filas, V.; Ibbs, M.; Bliźniak, R.; Łuczewski, Ł.; Lamperska, K. 2D and 3D cell cultures-A comparison of different types of cancer cell cultures. Arch. Med Sci. AMS 2018, 14, 910-919. [CrossRef]

51. Andersen, M.L.; Winter, L.M.F. Animal models in biological and biomedical research-experimental and ethical concerns. An. Acad. Bras. Ciênc. 2019, 91, e20170238. [CrossRef]

52. Li, F.; Yang, H.; Duan, Y.; Yin, Y. Myostatin regulates preadipocyte differentiation and lipid metabolism of adipocyte via ERK1/2. Cell Biol. Int. 2011, 35, 1141-1146. [CrossRef]

53. Hauner, H. Secretory factors from human adipose tissue and their functional role. Proc. Nutr. Soc. 2005, 64, 163-169. [CrossRef] [PubMed]

54. Trayhurn, P.; Drevon, C.A.; Eckel, J. Secreted proteins from adipose tissue and skeletal muscle-Adipokines, myokines and adipose/muscle cross-talk. Arch. Physiol. Biochem. 2011, 117, 47-56. [CrossRef] [PubMed]

55. Yang, F.; Cohen, R.N.; Brey, E.M. Optimization of Co-Culture Conditions for a Human Vascularized Adipose Tissue Model. Bioengineering 2020, 7, 114. [CrossRef] [PubMed]

56. Cui, H.X.; Guo, L.P.; Zhao, G.P.; Liu, R.R.; Li, Q.H.; Zheng, M.Q.; Wen, J. Method using a co-culture system with high-purity intramuscular preadipocytes and satellite cells from chicken pectoralis major muscle. Poult. Sci. 2018, 97, 3691-3697. [CrossRef] [PubMed]

57. Balistreri, C.R.; Caruso, C.; Candore, G. The Role of Adipose Tissue and Adipokines in Obesity-Related Inflammatory Diseases. Mediat. Inflamm. 2010, 2010, 802078. [CrossRef]

58. Leal, L.G.; Lopes, M.A.; Batista, M.L., Jr. Physical Exercise-Induced Myokines and Muscle-Adipose Tissue Crosstalk: A Review of Current Knowledge and the Implications for Health and Metabolic Diseases. Front. Physiol. 2018, 9, 1307. [CrossRef]

59. De Boer, A.A.; Monk, J.M.; Robinson, L.E. Docosahexaenoic acid decreases pro-inflammatory mediators in an in vitro murine adipocyte macrophage co-culture model. PLoS ONE 2014, 9, e85037. [CrossRef]

60. Kokta, T.A.; Dodson, M.V.; Gertler, A.; Hill, R.A. Intercellular signaling between adipose tissue and muscle tissue. Domest. Anim. Endocrinol. 2004, 27, 303-331. [CrossRef]

61. Pandurangan, M.; Hwang, I. Application of cell co-culture system to study fat and muscle cells. Appl Microbiol. Biotechnol. 2014, 98, 7359-7364. [CrossRef]

62. Yang, X.; Bi, P.; Kuang, S. Fighting obesity: When muscle meets fat. Adipocyte 2014, 3, 280-289. [CrossRef] 
63. Borciani, G.; Montalbano, G.; Baldini, N.; Cerqueni, G.; Vitale-Brovarone, C.; Ciapetti, G. Co-culture systems of osteoblasts and osteoclasts: Simulating in vitro bone remodeling in regenerative approaches. Acta Biomater. 2020, 108, 22-45. [CrossRef] [PubMed]

64. Zhang, Q.; Vashisht, A.A.; O’Rourke, J.; Corbel, S.Y.; Moran, R.; Romero, A.; Miraglia, L.; Zhang, J.; Durrant, E.; Schmedt, C.; et al. The microprotein Minion controls cell fusion and muscle formation. Nat. Commun. 2017, 8, 15664. [CrossRef] [PubMed]

65. Heng, B.C.; Cao, T.; Lee, E.H. Directing stem cell differentiation into the chondrogenic lineage in vitro. Stem Cells 2004, 22, 1152-1167. [CrossRef] [PubMed]

66. Zhang, Q.; Bu, S.; Sun, J.; Xu, M.; Yao, X.; He, K.; Lai, D. Paracrine effects of human amniotic epithelial cells protect against chemotherapy-induced ovarian damage. Stem. Cell Res. 2017, 8, 270. [CrossRef]

67. Zuo, Q.; Cui, W.; Liu, F.; Wang, Q.; Chen, Z.; Fan, W. Co-cultivated mesenchymal stem cells support chondrocytic differentiation of articular chondrocytes. Int. Orthop. 2013, 37, 747-752. [CrossRef]

68. Huang, C.P.; Lu, J.; Seon, H.; Lee, A.P.; Flanagan, L.A.; Kim, H.Y.; Putnam, A.J.; Jeon, N.L. Engineering microscale cellular niches for three-dimensional multicellular co-cultures. Lab Chip 2009, 9, 1740-1748. [CrossRef]

69. Ou, D.B.; Zeng, D.; Jin, Y.; Liu, X.T.; Teng, J.W.; Guo, W.G.; Wang, H.T.; Su, F.F.; He, Y.; Zheng, Q.S. The long-term differentiation of embryonic stem cells into cardiomyocytes: An indirect co-culture model. PLoS ONE 2013, 8, e55233. [CrossRef]

70. Pellegrinelli, V.; Rouault, C.; Rodriguez-Cuenca, S.; Albert, V.; Edom-Vovard, F.; Vidal-Puig, A.; Clément, K.; Butler-Browne, G.S.; Lacasa, D. Human Adipocytes Induce Inflammation and Atrophy in Muscle Cells During Obesity. Diabetes 2015, 64, 3121-3134. [CrossRef]

71. Grellier, M.; Bordenave, L.; Amedee, J. Cell-to-cell communication between osteogenic and endothelial lineages: Implications for tissue engineering. Trends Biotechnol. 2009, 27, 562-571. [CrossRef]

72. Renaud, J.; Martinoli, M.G. Development of an Insert Co-Culture System of Two Cellular Types in the Absence of Cell-Cell Contact. J. Vis. Exp. 2016, e54356. [CrossRef]

73. Lee, D.; Chambers, M. A co-culture model of the bovine alveolus. F1000Res 2019, 8, 357. [CrossRef] [PubMed]

74. Payne, J.A.; Rivera, C.; Voipio, J.; Kaila, K. Cation-chloride co-transporters in neuronal communication, development and trauma. Trends Neurosci. 2003, 26, 199-206. [CrossRef]

75. Saldaña, L.; Vallés, G.; Bensiamar, F.; Mancebo, F.J.; García-Rey, E.; Vilaboa, N. Paracrine interactions between mesenchymal stem cells and macrophages are regulated by 1,25-dihydroxyvitamin D3. Sci. Rep. 2017, 7, 14618. [CrossRef] [PubMed] 